\title{
Combine proper exercise and regular taking antihypertensive medicine was better to lower diastolic blood pressure among diastolic prehypertensive and hypertensive subjects
}

\author{
Ermita I. Ilyas, ${ }^{1}$ Bastaman Basuki, ${ }^{2}$ Dede Kusmana ${ }^{3}$ \\ ${ }^{1}$ Department of Physiology, Medical Faculty, University of Indonesia, Jakarta, Indonesia \\ ${ }^{2}$ Department of Community Medicine, Medical Faculty, University of Indonesia, Jakarta, Indonesia \\ ${ }^{3}$ Department of Cardiology and Cardiovascular, Medical Faculty, University of Indonesia, Jakarta, Indonesia
}

\begin{abstract}
Abstrak
Tujuan Untuk membuktikan bahwa olahraga yang sesuai dan minum obat dapat menurunkan tekanan darah diastolik (TDD) $\geq 5 \mathrm{mmHg}$.

Metode Penelitian eksperimen kuasi selama 8 minggu di antara karyawan suatu instansi di Jakarta bulan MaretAgustus 2008. Semua pengidap prahipertensi dan hipertensi yang ditemukan saat survei diundang mengikuti penelitian eksperimen kuasi. Ceramah diberikan pada awal penelitian, dan konseling sekali seminggu tentang olah raga, minum obat antihipertensi, serta hal terkait upaya penurunan TDD. Analisis memakai regresi Cox.

Hasil Sebanyak 1016 dari 1300 karyawan mengikuti survei tekanan darah, 318 subjek mempunyai TDD 80 mmHg atau lebih. Dari 120 subjek yang sukarela mengikuti eksperimen kuasi sebanyak 104 subjek yang menyelesaikannya. Dibandingkan dengan subjek yang tidak berolahraga dan juga tidak minum obat antihipertensi, subjek yang berolahraga sesuai dan minum obat antihipertensi teratur mempunyai kemungkinan penurunan TDD $\geq 5 \mathrm{mmHg} l e b i h$ 12 kali [risiko relatif suaian $(R R a)=12,32 ; 95 \%$ interval kepercayaan $(C I)=0,65-234,54 ; P=0,095]$, sedangkan subyek yang berolahraga sesuai atau minum obat antihipertensi namun tidak teratur mempunyai kemungkinan penurunan TDD $\geq 5 \mathrm{mmHg}$ hampir 11 kali $(R R a=10,94 ; 95 \% C I=2,04-58,74 ; P=0,05$. Subjek dengan TDD =90$99 \mathrm{mmHg}$ dibandingkan dengan yang $T D D=80-89 \mathrm{mmHg}$ mempunyai kemungkinan penurunan $T D D \geq 5 \mathrm{mmHg} 4,8$ kali $(R R a=4,75 ; 95 \% C I=1,19-18,65)$. Subjek yang obes, dengan denyut nadi istirahat bradikardia, serta tekanan nadi rata-rata tinggi tidak terjadi penurunan $T D D \geq 5 \mathrm{mmHg}$ dengan olahraga dan minum obat antihipertensi.
\end{abstract}

Kesimpulan Kombinasi olahraga sesuai dan minum obat antihipertensi menurunkan TDD $\geq 5 \mathrm{mmHg}$ di antara pengidap (pra-)hipertensi diastolik. Namun pada subjek yang obes, dengan denyut nadi istirahat bradikardi atau tekanan nadi rata-rata tinggi TDD tidak dapat diturunkan dengan olahraga dan minum obat antihipertensi. (Med J Indones 2010; 19: 191-8)

\begin{abstract}
Aim To prove that proper exercise and taking antihypertensive medicine may reduce diastolic blood pressure (DBP) by $\geq 5 \mathrm{mmHg}$.

Method A quasi-experimentation study was done on employees of a government bureau in Jakarta, for 8 weeks from March to August 2008. All prehypertensive and hypertensive subjects were detected through a survey prior to the quasi-experimentation study. A talk was given at the beginning of the quasi-experimentation study, and weekly counseling sessions on exercise, taking medications, and other related topics continued for 8 weeks. Cox regression was used for calculating relative risk.

Results A total 1,016 employees out of 1,300 were involved in this blood pressure survey. Of these, 318 subjects had a DBP of $80 \mathrm{mmHg}$ or more. Out of 120 subjects who voluntarily participated, 104 subjects completed the quasi-experimentation study. Compared to those who did not exercise properly and did not take antihypertensive medicines, subjects who did exercise properly and took medicines regularly had a lower diastolic blood pressure DBP $\geq 5 \mathrm{mmHg}$ by more than 12 fold [adjusted relative risk $(\mathrm{RRa})=12.32 ; 95 \%$ confidence interval $(\mathrm{CI})=0,65-234,54 ; \mathrm{P}=0.095$. However subjects who exercised properly or took antyhypertensive medicines irregularly were found to lower their $\mathrm{DBP} \geq 5 \mathrm{mmHg}$ by almost 11 fold [adjusted relative risk $(\mathrm{RRa})=10.94 ; 95 \%$ confidence interval $(\mathrm{CI})=2.04-58.74$ ]; $\mathrm{P}=0.005$. Subjects with $\mathrm{DBP}=90$ $99 \mathrm{mmHg}$ had a decrease of $\mathrm{DBP} \geq 5 \mathrm{mmHg} 4.8$ fold $(\mathrm{RRa}=4.75 ; 95 \% \mathrm{CI}=1.19-18.65)$ compared to those with $\mathrm{DBP}=$ $80-89 \mathrm{mmHg}$. Compared to the normal subjects, the obese, resting pulse rate bradycardia, and high average pulse pressure subjects had less probability of lowering DBP $\geq 5 \mathrm{mmHg}$, by $87 \%, 90 \%$, and $65 \%$, respectively.

Conclusion Combine proper exercise and taking antihypertensive medicine was reduce DBP by $\geq 5 \mathrm{mmHg}$ among DBP (pre-) hypertensive subjects. The obese, bradycardia, or high pulse pressure subjects failed to lowering their DBP $\geq 5 \mathrm{mmHg}$ by proper exercise and taking antihypertensive medicine. (Med J Indones 2009; 19: 191-8)
\end{abstract}

Key words: decreased diastolic blood pressure, exercise, medicine intake 
Since the 1970s there has been a progressive rise in hypertension in both developed and developing countries, such as Indonesia. ${ }^{1}$ The report of the Basic Health Research by the Ministry of Health (2008) noted that the average prevalence of hypertension is $32.0 \%$ among those aged 18 years or more. ${ }^{2}$

A cross sectional rural field study conducted by the Faculty of Medicine, University of Indonesia in 20012003 in West Java revealed that stage 1 and stage 2 hypertension was $37.6 \%$ among those aged 18 years or more. Of those $8,3 \%$ were currently taking pharmacological antihypertensive drugs. ${ }^{3}$ The Jakarta Cardiovascular cohort study (2007) among urban people noted that stage 1 and stage 2 hypertension was $41.6 \%$ among aged $25-95$ years, and $63.4 \%$ were currently taking pharmacological antihypertensive drugs. ${ }^{4}$

A reduction in DBP of $2 \mathrm{mmHg}$ reduces the risk of stroke by $17 \%$ and reduces the risk of coronary artery disease by $6 \%$ in the general population. A DBP $5 \mathrm{mmHg}$ higher than normal would, in the long term, be associated with about a $40 \%$ higher risk of death from stroke and about a $30 \%$ higher risk of death from IHD. ${ }^{5}$

Exercise became the focus of interest because various studies have found exercise to be beneficial in controlling hypertension. Several guidelines recommended exercise intervention for mild hypertension. However, for severe hypertension exercise with proper antihypertensive medication was recommended. ${ }^{5-7}$

Another study found that exercise significantly reduced both systolic and diastolic blood pressure among certain subjects while only systolic blood pressure was reduced for the other subjects. ${ }^{8}$ Another study concluded that aerobic exercise combined with weight training for 6 months can lower DBP, but not systolic blood pressure (SBP) in older adults (55-75 years). ${ }^{9}$ These results showed the different effects of exercise in lowering DBP compared to SBP.

Since proper exercise as a habit is difficult to bring about, counseling should be carried out to motivate active lifestyles and exercise. ${ }^{10}$

The aim of this study was to determine if proper exercise and taking medicine for 8 weeks may reduce $\mathrm{DBP} \geq 5 \mathrm{mmHg}$ among (pre-)hypertensive subjects.

\section{METHODS}

The subjects were goverment employees in Jakarta, males and females aged 20-60 years. The study was held at the office's clinic from March to August 2008. For the present analysis, we included all subjects who had DBP of $80 \mathrm{mmHg}$ or more (higher than optimal). Some subjects may also had systolic blood pressure of $120 \mathrm{mmHg}$ or more (higher than optimal). A total of 1,016 employees out of 1,300 employees participated in the first stage of blood pressure research (survey). We found 318 subjects (pre-)hypertensive in systolic and/or diastolic. A total of 120 voluntarily participated in the quasi experimentation study (second stage) for lowering blood pressure, and 104 of them who had DBP of $80 \mathrm{mmHg}$ or more were involved at the beginning of the second stage study. The quasi-experimentation study began with the signing of an informed consent document.

Furthermore, the first author talked on the management of hypertension, exercise recommendations, proper principles of exercise which consist of frekuency (3-4 times a week regularly), intensity (mild exercise), time/ duration (30-60 minutes) and type (aerobic exercise) $\{$ FITT $\}$ and how to determine pulse rate, etc. This was followed by individual light aerobic exercise programs lasting $30-60$ minutes 3 times a week for 8 weeks. Their activities were written in their logbooks.

Counseling was provided once a week to modify behavior in doing prescribed exercise. Medicine was prescribed by doctors at the clinic. Intense evaluation and observation was done continuously every week for 8 weeks. The outcome was the lowering of DBP by $\geq 5$ mmHg during 8 weeks of observation.

Demographic data were obtained by questionnaire, as was information on exercise or degree of physical activity, work-related stress and non work-related stress, and the use of antihypertensive medicine.

Physiological parameters such as body weight, height, body fat, blood pressure, pulse rate, and health problems were collected as baseline data. Body weight, blood pressure, and pulse rate were taken every week during counseling sessions, as was information about antihypertensive medicine.

Different methods were used to measure several parameters such as height, body weight, body fat percent, and blood pressure. Height and body weight were measured with a body weight scale (Health scale, ZT-120), skinfold thicknesses at the sites of triceps, chest, abdomen, suprailiac, and thigh were measured in $\mathrm{mm}$ with a skin-fold caliper (Lafayette, USA). Three skinfold thicknesses for men or women were used to calculate the percent of body fat using the Siri and 
Pollock table. ${ }^{11}$ Sitting blood pressure was measured twice in the right arm by the author between 8 to $12 \mathrm{AM}$ using a mercury sphygmomanometer after resting 5 to 10 minutes. Sitting resting pulse rate were measured in one minute.

Body Mass Index (BMI) was calculated from body weight $(\mathrm{kg})$ divided by height $(\mathrm{m})$ squared or $\mathrm{kg} / \mathrm{m}^{2}$, and categorized into 3 groups (low $=18.5$ or lower; normal=18.5-29.9; obesity $=30$ or greater).[12] Body fat percent was categorized into 3 groups for men (lean $=10 \%$ or lower; normal $=10 \%-19.9 \%$; obese $=20 \%$ or more) and for women (lean $=20 \%$ or lower; normal $=20 \%-29.9 \%$; obese $=30 \%$ or more). ${ }^{12}$

DBP on entry were categorized into 3 groups (80 $89 \mathrm{mmHg}$; $90-99 \mathrm{mmHg}$; and $100 \mathrm{mmHg}$ or more). ${ }^{6}$ Resting pulse rates were categorized into 3 groups (normal $=70-100$ beats $/$ minute, bradycardia $=<70$ beats/minute; tachycardia $=>100$ beats/minute).${ }^{12}$ Pulse pressures were categorized into 3 groups (low $=<20$ $\mathrm{mmHg}$; normal $=20-40 \mathrm{mmHg}$; high $=>40 \mathrm{mmHg}) .{ }^{13}$

Proper exercise is the exercise regimen prescribed that conforms to the general principles of F.I.T.T. based on the JNC 7 or other guidelines (aerobic exercise, 3 times a week, 30-60 minutes, regularly). ${ }^{6,7}$ Regular medicine intake is an antihypertensive medicine that should be taken regularly as prescribed by doctors at the clinic.

Statistical analysis was done using STATA 9.0 software. Analysis of risk factors related to lower diastolic blood pressure at the beginning and during observation used Cox regression..$^{14}$ Ethical clearance was issued by the Ethical Commission of Medical Faculty of the University of Indonesia.

\section{RESULTS}

As much as $15,4 \%(16 / 104)$ of the subjects had decreased DBP at least $5 \mathrm{mmHg}$. Table 1 shows that $76 \%(79 / 104)$ of the subjects were men, 51\% (53/104) of the subjects were in the 45-54 age group, the initial pulse rate of $82 \%(85 / 104)$ of the subjects indicated bradycardia, and $83 \%(86 / 104)$ of the subjects had a high initial pulse rate. Furthermore, Table 1 shows that those with stable and decreased DBP were similarly distributed in terms of gender, age group, and high resting pulse pressure at the beginning of observation. However, tachycardia subjects were more likely to have decreased DBP.

Table 1. Some of demographic, risk factors of hypertension at the beginning of observation and the risk of lowering DBP

\begin{tabular}{|c|c|c|c|c|c|}
\hline & \multicolumn{2}{|c|}{$\begin{array}{c}\text { Diastolic blood } \\
\text { pressure }\end{array}$} & \multirow{2}{*}{$\begin{array}{l}\text { Relative } \\
\text { risk }\end{array}$} & \multirow{2}{*}{$\begin{array}{c}95 \% \\
\text { Confidence } \\
\text { Interval }\end{array}$} & \multirow[t]{2}{*}{$P$} \\
\hline & $\begin{array}{l}\text { Stable } \\
(n=88)\end{array}$ & $\begin{array}{c}\text { Decreased } \\
(n=16)\end{array}$ & & & \\
\hline \multicolumn{6}{|l|}{ Gender } \\
\hline Women & 22 & 3 & 1.00 & Reference & \\
\hline Men & 66 & 13 & 0.87 & $0.32-4.08$ & 0.829 \\
\hline \multicolumn{6}{|l|}{ Age } \\
\hline $25-34$ & 8 & 1 & 1.00 & Reference & \\
\hline $35-44$ & 23 & 6 & 1.92 & $0.23-16.08$ & 0.588 \\
\hline $45-54$ & 46 & 7 & 1.42 & $0.17-11.95$ & 0.745 \\
\hline $55-64$ & 11 & 2 & 1.67 & $0.15-18.48$ & 0.675 \\
\hline \multicolumn{6}{|l|}{$\begin{array}{l}\text { Initial pulse } \\
\text { rate }\end{array}$} \\
\hline Normal & 12 & 1 & 1.00 & Reference & \\
\hline Bradycardia & 71 & 14 & 2.94 & $0.38-22.52$ & 0.300 \\
\hline Tachycardia & 5 & 1 & 6.07 & $0 ., 37-99.95$ & 0.207 \\
\hline \multicolumn{6}{|l|}{$\begin{array}{l}\text { Initial pulse } \\
\text { pressure }\end{array}$} \\
\hline Normal & 13 & 5 & 1.00 & Reference & \\
\hline High & 75 & 11 & 0.55 & $0.19-1.59$ & 0.271 \\
\hline
\end{tabular}

Table 2 shows that most of the subjects, $66.3 \%(69 / 104)$ were not taking antihypertensive medicine, 30\% ((31/104) were taking one kind of antihypertensive medicine, $21 \%(22 / 104)$ of were taking antihypertensive medicine regularly, 32\% (33/104) were taking antihypertensive medicine once a day, and 30\% (31/104) were not experiencing stressors related to problems with children. Table 2 also shows that stable DBP and decreased DBP at the beginning of observation were equally distributed in terms of irregularity of medicine intake, and frequency of psychosocial stressors caused by problem with children. Subjects taking 1 or 2 types of drugs, those with regular drug intake, and subjects taking $1-2$ doses per day tended to have lower DBP. Subjects taking 2 types of antihypertensive medications had lower DBP compared to those taking medications only 1 type of drug. Subjects taking antihypertensive drugs twice daily had lower DBP than those taking medications only once a day. Infrequent psychosocial stress tended to reduce the probability of decrease DBP. 
Table 2. Medicine intake habits and psychosocial stressors at the beginning of observation and the risk of lowering DBP

\begin{tabular}{|c|c|c|c|c|c|}
\hline & \multicolumn{2}{|c|}{$\begin{array}{l}\text { Diastolic blood } \\
\text { pressure }\end{array}$} & \multirow{2}{*}{$\begin{array}{c}\text { Relative } \\
\text { risk }\end{array}$} & \multirow{2}{*}{$\begin{array}{c}95 \% \\
\text { Confidence } \\
\text { Interval }\end{array}$} & \multirow{2}{*}{$P$} \\
\hline & $\begin{array}{l}\text { Stable } \\
(\mathrm{n}=88)\end{array}$ & $\begin{array}{c}\text { Decreased } \\
(\mathrm{n}=16)\end{array}$ & & & \\
\hline \multicolumn{6}{|l|}{ Type of drug } \\
\hline Not taking & 62 & 7 & 1.00 & Reference & \\
\hline 1 kind & 24 & 7 & 2.85 & $0.95-8.49$ & 0.016 \\
\hline 2 kinds & 2 & 2 & 6.13 & $1.19-31.44$ & 0.030 \\
\hline \multicolumn{6}{|l|}{$\begin{array}{l}\text { Regularity of } \\
\text { medicine intake }\end{array}$} \\
\hline Not taking & 62 & 7 & 1.00 & Reference & \\
\hline Irregular & 11 & 2 & 1.80 & $0.37-8.74$ & 0.887 \\
\hline Regular & 15 & 7 & 4.06 & $1.41-11.70$ & 0.009 \\
\hline \multicolumn{6}{|l|}{ Dose of medicine } \\
\hline Not taking & 62 & 7 & 1.00 & Reference & \\
\hline Once a day & 25 & 8 & 3.05 & $1.10-8.47$ & 0.032 \\
\hline Twice a day & 1 & 1 & 4.78 & $0.57-40.13$ & 0.150 \\
\hline \multicolumn{6}{|l|}{$\begin{array}{l}\text { Stressor related to } \\
\text { children problem }\end{array}$} \\
\hline None & 24 & 7 & 1.00 & Reference & \\
\hline Sometimes & 42 & 4 & 0.38 & $0.11-1.31$ & 0.125 \\
\hline Often or always & 22 & 5 & 0.86 & $0.26-2.77$ & 0.797 \\
\hline
\end{tabular}

Table 3 shows that during observation, 63\% (65/104) of the subjects were not taking antihypertensive medicine. $34 \%(35 / 104)$ of the subjects were taking one kind of antihypertensive medicine, 20\% (21/104) were taking antihypertensive medicine regularly, 36\% (37/104) were taking antihypertensive medicine once a day, 55\% (57/104) had 1-3 counseling visits, 33\% (34/104) had 5-8 counseling visits. Table 3 also shows that stable and lowered DBP during observation were similarly distributed in terms of number of visits (4 times). Subjects taking 2 types of medicine, regular medicine intake, taking daily doses of medicine, and having 5-8 counseling visits tended to have lower DBP. Taking 2 types of medicines and regular medicine intake appeared to be more effective in lowering DBP than taking 1 type of medicine and irregular medicine intake.

Compared to the beginning of observation, the DBP of subjects not taking antihypertensive medicine decreased 3\% during observation, subjects taking one kind of antihypertensive medicine increased $4 \%$, those taking regularly decreased $1 \%$ and subjects taking antihypertensive medicine once a day increased 3\%. It can be assumed that the decrease of DBP by those subjects regularly taking antihypertensive medicine was caused by exercise that they had done.

Table 4 (final model) shows that compared to those with no exercise and no medication, those subjects who combine the recommended exercise with compliance to treatment regimen tended to lower their DBP by 12 fold ( $\mathrm{RRa} 12.32 ; 95 \% \mathrm{CI}=0.65-234.54)$, even though the power/the significancy was not very $\operatorname{good}(\mathrm{p}=0.95)$. This table also shows the subjects who adhered to the recommended exercises tended to lower DBP $\geq 5$ $\mathrm{mmHg}$ by almost 11 fold [adjusted relative risk (RRa) 10.94; $95 \% \mathrm{CI}=2.04-58.74]$ compared to those with no exercise and no medication. Subjects who exercised but not according to recommendations also lowered their DBP by 2 fold (RRa 2.41; 95\% Nevertheless, the intervention for diastolic blood pressure must also be accompanied by regular medicine intake.

Table 3. Medicine intake habits of subject and number of visits for counseling during observation and the risk of lowering DBP

\begin{tabular}{|c|c|c|c|c|c|}
\hline & \multicolumn{2}{|c|}{$\begin{array}{l}\text { Diastolic blood } \\
\text { pressure }\end{array}$} & \multirow{2}{*}{$\begin{array}{l}\text { Relative } \\
\text { risk }\end{array}$} & \multirow{2}{*}{$\begin{array}{c}95 \% \\
\text { Confidence } \\
\text { Interval }\end{array}$} & \multirow{2}{*}{$P$} \\
\hline & $\begin{array}{l}\text { Stable } \\
(\mathrm{n}=88)\end{array}$ & $\begin{array}{l}\text { Decreased } \\
(\mathrm{n}=16)\end{array}$ & & & \\
\hline \multicolumn{6}{|l|}{ Type of drug } \\
\hline Not taking & 58 & 7 & 1.00 & Reference & \\
\hline 1 kind & 28 & 7 & 2.68 & $0.90-8.00$ & 0.078 \\
\hline 2 kinds & 2 & 2 & 6.03 & $1.17-31.00$ & 0.031 \\
\hline \multicolumn{6}{|c|}{$\begin{array}{l}\text { Regularity of } \\
\text { medicine intake }\end{array}$} \\
\hline Not taking & 58 & 7 & 1.00 & Reference & \\
\hline Irregular & 14 & 4 & 2.44 & $0.69-8.66$ & 0.167 \\
\hline Regular & 16 & 5 & 3.82 & $1.15-12.73$ & 0.029 \\
\hline \multicolumn{6}{|c|}{ Dose of medicine } \\
\hline Not taking & 58 & 7 & 1.00 & Reference & \\
\hline Once a day & 28 & 9 & 3.19 & $1.13-9.00$ & 0.028 \\
\hline Twice a day & 2 & 0 & n.a. & & \\
\hline \multicolumn{6}{|c|}{ Number of visits } \\
\hline $1-3$ times & 49 & 8 & 1.00 & Reference & \\
\hline 4 times & 10 & 1 & 1.12 & $0.14-9.05$ & 0.914 \\
\hline $5-8$ times & 29 & 7 & 1.87 & $0.67-5.27$ & 0.235 \\
\hline
\end{tabular}


Table 4. The relationship between the combination of proper exercise and regularity of medicine intake and others dominant factors at the beginning and during observation to the risk of lowering DBP

\begin{tabular}{|c|c|c|c|c|c|}
\hline & \multicolumn{2}{|c|}{ Diastolic blood pressure } & \multirow[b]{2}{*}{$\begin{array}{c}\text { Adjusted } \\
\text { Relative Risk* }\end{array}$} & \multirow[b]{2}{*}{$\begin{array}{l}95 \% \text { Confidence } \\
\text { Interval }\end{array}$} & \multirow[b]{2}{*}{$P$} \\
\hline & $\begin{array}{l}\text { Stable } \\
(\mathrm{n}=88)\end{array}$ & $\begin{array}{l}\text { Decreased } \\
\quad(\mathrm{n}=16)\end{array}$ & & & \\
\hline \multicolumn{6}{|l|}{$\begin{array}{l}\text { Exercise and medicine intake during } \\
\text { observation }\end{array}$} \\
\hline No exercise and not taking medicine & 4 & 1 & 1.00 & Reference & \\
\hline $\begin{array}{l}\text { Not proper exercise or regular } \\
\text { medicine }\end{array}$ & 55 & 8 & 2.41 & $0.66-8.75$ & 0.183 \\
\hline Proper exercise or irregular medicine & 25 & 6 & 10.94 & $2.04-58.74$ & 0.005 \\
\hline Proper exercise and regular medicine & 4 & 1 & 12.32 & $0.65-234.54$ & 0.095 \\
\hline \multicolumn{6}{|l|}{$\begin{array}{l}\text { Diastolic blood pressure at the } \\
\text { beginning observation }\end{array}$} \\
\hline $80-89 \mathrm{mmHg}$ & 46 & 6 & 1.00 & Reference & \\
\hline $90-99 \mathrm{mmHg}$ & 27 & 8 & 4.75 & $1.19-18.65$ & 0.027 \\
\hline $100 \mathrm{mmHg}$ or more & 15 & 2 & 2.26 & $0.36-14.24$ & 0.386 \\
\hline \multicolumn{6}{|l|}{ Resting pulse rate during observation } \\
\hline Normal & 33 & 3 & 1.00 & Reference & \\
\hline Bradycardia & 53 & 13 & 0.10 & $0.02-0.50$ & 0.005 \\
\hline Tachycardia & 2 & 0 & n.a. & & \\
\hline \multicolumn{6}{|l|}{$\begin{array}{l}\text { Average pulse pressure during } \\
\text { observation }\end{array}$} \\
\hline Normal & 28 & 7 & 1.00 & Reference & \\
\hline High & 59 & 9 & 0.35 & $0.11-1.10$ & 0.073 \\
\hline \multicolumn{6}{|l|}{$\begin{array}{l}\text { Body fat at the beginning of } \\
\text { observation }\end{array}$} \\
\hline Normal & 16 & 6 & 1.00 & Reference & \\
\hline Low & 1 & 0 & n.a. & & \\
\hline Obese & 71 & 10 & 0.13 & $0.04-0.46$ & 0.001 \\
\hline
\end{tabular}

$\mathrm{CI}=0.66-8.75)$ compared to those who did no exercise and took no medication. Subjects with $\mathrm{DBP}=80 \mathrm{mmHg}$ or more compared to subjects with DBP lower than $80 \mathrm{mmHg}$ tended to lower their DBP $\geq 5 \mathrm{mmHg}$ by 4.8 fold $(\mathrm{RRa} 4.75 ; 95 \% \mathrm{CI}=1.19-18.65)$. In addition, obesity, resting pulse rate (bradycardia), and also high average pulse pressure during the observation tended to inhibit the decrease of DBP.

\section{DISCUSSION}

There were several limitations in this study. Firstly, information bias or recall bias may occur, even though to minimize this problem, medical personnel of the clinic guided the completion of the questionnaires to help subjects understand the aim of each question. Secondly. in the quasi-experimentation design of this study physical exercise and compliance to treatment regimen cannot be directly controlled but were noted down by the subjects themselves and the notes were presumed to be reliable. It is hoped that applying an intervention model such as this will be easier in the community and the resulting effect will be known throughout the study. Thirdly, the number of samples may not be a sufficient representative of subjects with $\mathrm{DBP}=80 \mathrm{mmHg}$ or more, limited data associated with history of disease, and personal habits are also as a part of limitation in this study.

According to the characteristic of the subjects (table 1) $83 \%$ subjects had high initial pulse pressures of DBP = $80 \mathrm{mmHg}$ or more. Most of subjects (67\%) were less than 50 years old, and $15 \%$ of the subjects had pulse pressures of 60 and higher. This shows that this population needs full attention to or regular blood pressure monitoring. Another study recommended monitoring individuals with high normal blood pressure $(\mathrm{DBP}=85-89 \mathrm{mmHg}$ ) once a year and monitoring those with normal blood pressure $(\mathrm{DBP}=80-84 \mathrm{mmHg}$ ) once every 2 years. This recommendation is based on their finding that high normal blood pressure and normal blood pressure frequently progresses to hypertension over a period of 4 years. ${ }^{15}$ At the beginning of observation, shows decrease DBP higher in men than women, mostly in 
the 35-54 age group. Most subjects with bradycardia, high initial pulse pressure of $\mathrm{DBP}=80 \mathrm{mmHg}$ or more had a decreased probability of reducing their DBP than those with DBP lower than $80 \mathrm{mmHg}$. It was likely that men compared to women, would reduce their DBP. It was less likely that subjects with bradycardia would reduce their DBP, but subjects with tachycardia may lowering their DBP better than normal pulse rate.

According to Chobanian, controlling SBP, is more important as a CVD risk factor than DBP except in patients younger than 50 and it is considerably more difficult to control SBP than DBP. ${ }^{6}$ Ours findings shows that the subjects who had DBP $=80 \mathrm{mmHg}$ or more were mostly in age group 35-54 years old, and it was noted that stable DBP and decreased DBP were similarly distributed in term of age groups.

We also found during our quasi-experimentation study that only $15,4 \%$ of the subjects had decreased DBP $\geq 5$ $\mathrm{mmHg}$. This showed that efforts to decrease DBP were very difficult.

Compared to the beginning of observation, subjects who did not taking antihypertensive medicine decreased their DBP 3\% during observation, subjects taking one kind of antihypertensive medicine increased $4 \%$, those taking regularly decreased $1 \%$ and subjects taking once a day increased 3\%. The decreased DBP in those subjects who have been regularly taking antihypertensive medicine may be due to exercise they already doing. This study showed that the compliance of visits for counseling was very low, and according to subjects this is caused because they are very busy with their work.

In term of antyhypertensive medicine intake, taking two kinds of medicine, regular intake, and taking medicine twice a day resulted in a higher probability of lowering DBP compared to subjects not taking antihypertensive medicine.

Family stressors also found tended to prevent the decrease of a subject's DBP. However subjects who had psychosocial stressors sometimes had less probability to decrease DBP compared to those subjects who often/ always suffered from psychosocial stressor.

In this quasi-experimentation study, the dominant risk factors for lowering DBP include a combination of exercise and compliance to a treatment regimen, which lowered DBP more than 12 fold compared to subjects with no exercise and taking no medicine. The decrease was moderately significant. This was probably due to insufficient strength of the power $(\mathrm{P}=0.095)$ and may be due to an insufficient number in the sample size. This result differed from results in a 1990 study, which found that drug therapy has no additional benefit to the antihypertensive effects of exercise. ${ }^{16}$ However, lowto-moderate intensity aerobic exercise can help mildly hypertensive patients and reduce drug dosage of those more severely affected. ${ }^{17}$

Ours study also showed the subjects who exercise properly were found to lower their DBP $\geq 5 \mathrm{mmHg}$ by almost 11 fold [adjusted relative risk $(\mathrm{RRa})=10.94 ; 95 \%$ confidence interval $(\mathrm{CI})=2.04-58.74]$. Several studies also found that proper exercise can reduce blood pressure (both SBP and DBD) among hypertensive subjects. ${ }^{9,17-19}$ This result is consistent with another study that found reductions in DBP by aerobic exercise were greater in Asians compared with whites and blacks. ${ }^{20}$

Subjects who practiced exercise but did not have exercise properly were found to lower their DBP $\geq$ $5 \mathrm{mmHg}$ by more 2 folds. Our result in accordance with another study that found no such exercise doseresponse relation in lowering DBP. ${ }^{18}$

Our multivariate analysis noted a contrast result. Subjects who took antihypertensive medicine irregularly may have more decreased DBP than subjects who took antihypertensive medicine regularly during observation. This result may be because those who took medicine irregularly were subjects who took 2 kinds of medicine.

In term of subjects visits for counseling, subjects who visited 5-8 times during the 8 weeks of observation tended to lower their DBP compared to subjects who visit 1-3 times.

This study also shows low rates of compliance of the subjects even though this study under close supervision. This condition demonstrates the difficulty of patient control in measuring their blood pressure, and it was also in accordance with another public health studies. ${ }^{6}$

Subjects with DBP between 90-99 $\mathrm{mmHg}$ during observation had a 4 fold reduction in diastolic blood pressure compared to subject with DBD between $80-89 \mathrm{mmHg}$, and we found same result with at the beginning of observation (table 1). This is showed that a DBP between 90-99 $\mathrm{mmHg}$ can be reduced through proper exercise. Subjects who had a DBP between 90$99 \mathrm{mmHg}$ consisted of a vast majority of hypertensive individuals. ${ }^{21}$ This finding showed the benefits of exercise to decreasing DBP in subject with DBP 
between 90-99 mmHg. However, exercise combined with antihypertensive medicine showed a higher probability for lowering DBP.

The JNC-V and JNC-VI mentioned, emphasized SBP and DBP levels equally in determining blood pressure stage and for treatment. The Framingham study found that only stage 2 or higher hypertension predicted initiation of therapy, whereas hypertension stage 1 did not. The Framingham study found patient with hypertension stage 1 may not have had consistently elevated BP when seen by their physician, making them less likely to initiate treatment. ${ }^{21}$

Our study noted that obesity seemed to reduce the probability of lowering DBP. This showed a direct relationship between obesity or the amount of body fat with increased DBP. According to Zamani, this relationships may be caused by the release of angiotensinogens from adipocyte, augmented by blood volume related to increased body mass and increase blood viscosity caused by adipocity release of profibrinogen and plasminogen activator inhibitor 1.22 This is supported by another study which noted the combination of regular exercise and weight loss is effective in lowering resting blood pressure. ${ }^{5}$ People who were most likely to lower both systolic and diastolic blood pressures were those who lost the most body fat. ${ }^{9}$

Bradycardia resting pulse rate tended to decrease the probability of lowering DBP compared to normal resting pulse rate. This result needs more confirmation, since multiple epidemiological surveys have shown that an elevated heart rate is an independent predictor of the development of hypertension, and both elevation of heart rate or decreased heart rate variability are predictors of cardiovascular mortality. ${ }^{23}$

High average pulse pressure during observation tended to decrease the probability of lowering DBP compared to the reference. Pulse pressure slightly increased in the 50-55 age group and increased progressively after age $60 .{ }^{24}$ In ours quasi-experimentation study, $79 \%$ of the subjects in the $35-54$ age group, $83 \%$ with high average pulse pressure and $15 \%$ of them had very high (more than 60) average pulse pressure. Compared to the beginning of observation, subjects with high pulse pressure decreased to $66 \%$ during observation and subjects with very high pulse pressure decreased to $10.57 \%$.

From this study, it can be said that exercise according to recommendations will lower DBP. Therefore, it is necessary to study further the role of exercise according to recommendation and regular medicine intake on lowering DBP compared to other combinations of intervention. Since obesity reduces the probability of lowering DBP, overweight or obese prehypertensive and hypertensive patients should exercise not only aimed at reducing blood pressure but also to control weight and blood lipid levels. Blood pressure, body fat, and blood lipid levels should be regularly monitored.

In conclusion, combine proper exercise and taking antihypertensive medicine was better to reduce DBP by $\geq 5 \mathrm{mmHg}$ among DBP (pre-) hypertensive subjects. The obese, bradycardia, or high pulse pressure subjects failed to lowering their DBP $\geq 5 \mathrm{mmHg}$ by proper exercise and taking antihypertensive medicine. Employees of this government office are advised to maintain light aerobic exercises, 3-4 times/week, 30-60 minutes regularly. Improving compliance to antihypertensive treatment regimen is needed.

\section{Acknowledgments}

The authors wish thank all subjects who participated in this study. The authors would like to express their sincerest gratitude for the former Secretary General of Parliament, Faisal Djamal, SH and Secretary General of Parliament Dra. Nining Indra Saleh, MSi and also to Ir. Ichwan Ishak, a member of 2004-2009 Parliament, for their support in making this study possible. The authors are also very grateful to Dr. Elisabeth Emerson who made this final draft better.

Parts of this study have been presented in the $5^{\text {th }}$ Malaysia Indonesia Brunei Medical Sciences Conference 2009 in Jakarta.

\section{REFERENCES}

1. Appel LJ, Champagne CM, Harsha D, Cooper LS. Effects of comprehensive lifestyle modification on blood pressure control. JAMA. 2003;289:2083-93.

2. National research report of the ministry of health. Basic medical research 2007 [in Indonesian].[Cites 2008 March 13]. Available from http://www.litbang.depkes.go.id/Laporan.

3. Basuki B, Siagian M, Ilyas EI, Amri Z. Combined traditional medicine and pharmacological antihypertensive drugs in a rural community of West Java, Indonesia. Med J Indones. 2004;13:246-51.

4. Kusmana D. Jakarta cardiovascular study: Report I. Jakarta: RSJHK; 2008

5. Pescatello LS, Franklin BA, Fagard R, Farquhar WB, Kelley GA, Ray CA. Exercise and hypertension. Med Sci Sports Exerc. 2004; 533-53. 
6. Chobanian AV, Bakris GL, Black HR, Cushman WC, Green LA, Izzo JL, et al. The seventh report of the Joint National Committee on prevention, detection, evaluation, and treatment of high blood pressure. JAMA. 2003;289:2560-72.

7. AACE Guidelines. American Association of clinical endocrinologists medical guidelines for clinical practice for diagnosis and treatment of hypertension. AACE hypertension task force. Endocrine Practice.2006;12:193-222.

8. Kinoshita A, Urata H, Tanabe Y, Ikeda M, Tanaka H, Shindo $\mathrm{M}$, et al. What types of hypertensive respond better to mild exercise therapy. J Hypertension.1988;6:S631-3.

9. Stewart KJ, Bacher AC, Turner KL, Fleg JL, Hees PS, Shapiro EP, et al. Effect of exercise on blood pressure in older persons. A Randomized controlled trial. Arch Intern Med.2005;165:756-62.

10. Eden KB, Orleans TC, Mulrow CD, Pender NJ, Teutsch SM. Clinician counseling to promote physical activity. Systematic evidence review no.9. Prepared by Oregon Health Sciences University Evidence-based Practice Centre under contract no.290-97-0018. Rockville, MD: Agency for Healthcare Research and Quality; 2002 [Cited 2008 March 16]. Available from: http://www.ahrq.gov/clinic/sertifiles.htm.

11. Kirkendall DR, Gruber JJ, Johnson RE. Measurement and evaluation for physical educators. 2nd ed. Champaign IL: Human Kinetics Publishers Inc;1987:56-80.

12. WHO Expert Consultation. Appropriate body-mass index for Asian populations and its implications for policy and intervention strategies. Lancet. 2004; 363: 157-63.

13. Sherwood L. Human physiology: from cells to systems. 5th ed.Belmont,CA: Thomson; 2004.

14. Barros AJD, Hirakata VN. Alternative for logistic regression in cross-sectional studies: an empirical comparison of models that directly estimates the prevalence ratio. BMC Medical Research Methodology. 2003 Oct [Cited 2007 June 6]; 3
(21). Available from: http://www.biomedcentral.com/14712288/3/21.

15. Vasan RS, Larson MG, Leip EP, Kannel WB, Levy D. Assessment of frequency of progression to hypertension in non-hypertensive participants in the Framingham Heart Study: a cohort study. Lancet. 2001: 358:1682-86.

16. Kelemen MH, Effron MB, Valenti SA, Stewart KJ. Exercise training combined with antihypertensive drug therapy. Effects on lipids, blood pressure, and left ventricular mass. JAMA. 1990;263:2766-71.

17. Chintanadilok J, Lowenthal DT. Exercise in treating hypertension. The Physician and Sports Medicine. 2002; 30:1-10.

18. Duncan JJ, Farr JE, Upton SJ, Hagan RD, Oglesby ME, Blair SN. The effects of aerobic exercise on plasma cathecolamines and blood pressure in patients with mild essential hypertension. JAMA.1985; 254:2609-13.

19. Takata KI, Ohta T, Tanaka H. How much exercise is required to reduce blood pressure in essential hypertensives: A doseresponse study. Am J Hypertens. 2003:16:629-33.

20. Pescatello LS, Fargo AE, Leach CN, Scherzer HH. Shortterm Effect of Dynamic Exercise on Arterial Blood Pressure. Circulation 1991;83:1557-61.

21. Lloyd-Jones DM \& Evans JC, Larson MG, Levy D. Treatment and control of hypertension in the community. A prospective analysis. Hypertension.2002:40:640-6.

22. Zamani P, Williams GH, Lilly LS. Hypertension. In Pathophysiology of heart disease. 4th ed. Philadelphia: Lippincott Williams \& Wilkins; 2007: p. 311-33.

23. Kaplan NM. Clinical hypertension. 9th ed. Philadelphia: Lippincott Williams \& Wilkins; 2006.

24. Simons-Morton DG. Exercise Therapy. Hypertension Primer. In: The essentials of high blood pressure. Basic science, Population science, and clinical management. 4th ed. Philadelphia: Williams \& Wilkins; 2008: p. 410-3. 